\title{
UNICOMPARTIMENTAL KNEE ARTHROPLASTY - 15 YEARS FOLLOW UP
}

\author{
ARTROPLASTIA UNICOMPARTIMENTAL DO \\ JOELHO - 15 ANOS DE SEGUIMENTO
}

\author{
Gilberto Luis Camanho ${ }^{1}$ id
}

1. Universidade de São Paulo, Medical School, Hospital das Clínicas, Orthopedics and Traumatology Institute, São Paulo, SP, Brazil.

\section{ABSTRACT}

Objective: To evaluate clinically and radiologically the long-term follow-up of patients with anteromedial osteoarthritis who underwent unicompartmental knee arthroplasty surgery. Methods: This study included 36 patients who underwent unicompartmental knee arthroplasty surgery for medial compartmental osteoarthritis with a minimum of 15-year post-operative follow-up. All surgeries were performed by a single surgeon (G.L.C) using the Miller-Galante unicompartmental knee implant. Patients were analyzed regarding their clinical functional and implant radiographic conditions. Results: From the 46 patients who could have completed 15 years of follow-up, three required revision surgery with conversion to total knee arthroplasty (6.5\%), 36 completed the 15-year follow-up period, and the others were lost to follow-up for reasons not related to unicompartmental arthroplasty. Conclusion: In these 36 patients, the result was satisfactory after follow-up, with complaints and sign of progression of osteoarthritis in some cases. Level of Evidence IV, Case series.

\section{RESUMO}

Objetivo: Avaliar clínica e radiologicamente o acompanhamento a longo prazo de pacientes com osteoartrite anteromedial do joelho que passaram por cirurgia de artroplastia total do joelho. Métodos: Este estudo incluiu 36 pacientes que se submeteram à artroplastia unicompartimental do joelho por lesão do compartimento medial provocada por artrose com, no mínimo, 15 anos de acompanhamento pós-operatório. Todas as cirurgias foram realizadas pelo mesmo cirurgião (G.L.C.) utilizando uma prótese unicompartimental tipo Miller-Galante. Os pacientes foram analisados quanto as suas condições clínicas e condições radiográficas do implante. Resultados: Dos 46 pacientes que poderiam ter concluído 15 anos de acompanhamento, 3 necessitaram de revisão com artroplastia total (6,5\%); 36 concluíram os 15 anos de acompanhamento, e o restante abandonou o acompanhamento por razões independentes da artroplastia unicompartimental. Conclusão: Nestes 36 pacientes, o resultado foi satisfatório após o acompanhamento, com queixas e sinais de progressão da artrose em alguns casos. Nível de Evidência IV, Série de casos.

Keywords: Knee. Arthroplasty. Arthrosis.

Descritores: Joelho. Artroplastia. Artrose.

Citation: Camanho GL. Unicompartimental knee arthroplasty - 15 years follow up. Acta Ortop Bras. [online]. 2020;28(5):233-235. Available from URL: http://www.scielo.br/aob.

\section{INTRODUCTION}

Arthrosis of the medial compartment of the knee is an evolutionary pathology in most cases. This disease occurs due to a muscle imbalance, resulting in the prevalence of flexor medial muscles and internal rotators on the quadriceps and external rotator lateral flexors. The loss of muscle strength, physiological with age, firstly affects larger muscles at the beginning, and quadriceps atrophy is the most important in lower limb.

There are several stages, but while the knee remains stable, that is, with the anterior cruciate ligament integrated, valgus osteotomy is a good indication in young patients and in older adults, unicompartmental knee arthroplasty (UKA) is the best indication. Unicompartmental knee arthroplasty has a variable concept in the orthopedic environment. Firstly, some issues were reported in the Brazilian and American orthopedic literature. In Brazil, Veiga et al.," in 1997, published discouraging results in Brazilian literature. Survival has always been questioned and it was considered that the limit would be 10 years, short in relation to total arthroplasty.

We performed 94 unicompartmental knee arthroplasties over 25 years, for several indications, but medial arthrosis was the most frequent indication.

We publish the results ${ }^{2}$ to 10 years of follow-up, we will study in this paper the evolution of 36 patients who reached 15 years or more.

\section{MATERIALS AND METHODS}

We considered 36 patients operated by us who reached at least 15 years of evolution after undergoing unicompartmental knee arthroplasty. 
Regarding the distribution according to sex, 21 patients are women, and the most affected side was the left side in 19 patients.

The age ranged between 76 and 91 years, with a higher concentration in the 85-year age group.

We had 46 patients who would have had 15 years of UNI arthroplasty:

- three underwent total arthroplasty due to problems in the unicompartmental prosthesis, and they did not complete 15 years of follow-up.

- one suffered tibial plateau fracture after fall and underwent total arthroplasty

- six died from causes other than the surgery

- 36 were studied in this study, as they have completed 15 years of follow-up

Our intention was to evaluate UKA behavior in patients with 15 years of evolution of the surgery.

Patients had surgical indication due to cartilage involvement of the medial compartment of the knee, they were selected to undergo UKA, because they had stable knees, according to Ahlbäck classification. $^{3}$

All patients were operated by the author using a Miller-Galante unicompartmental prosthesis, marketed by Zimmer and they were initially followed every 3 months in the first year, and thereafter each year, or when they had any complaint.

We considered for this study patients with follow-up of at least 15 years and who had at least one radiograph after the 15th year of follow-up.

We analyzed patient satisfaction and radiographs regarding the progression of arthrosis and deformity. We did not use the Knee International Society system, because they are patients of advanced age and the have limitations on age-specific locomotion.

Regarding satisfaction, we use the following criteria: spontaneous pain, pain at rest, limitation to walk more than 100 meters, use of cane for balance.

Regarding for radiography, the criteria used were lateral arthrosis, patellofemoral arthrosis, worsening of varus deviation, prosthesis loosening.

\section{RESULTS}

\section{Regarding satisfaction}

$\begin{array}{ll}\text { Spontaneous pain } & 4 / 36 \\ \text { Pain at rest } & 1 / 36 \\ \text { Limitation } 100 \mathrm{~m} & 5 / 36 \\ \text { Cane } & 3 / 36\end{array}$

\section{Radiography}

Lateral arthrosis $2 / 36$

Patellofemoral Arthrosis

Worsening of varus

Prosthesis loosening

\section{$5 / 36$ (Figure 1) \\ 2/36 (Figure 2) \\ $0 / 36$}

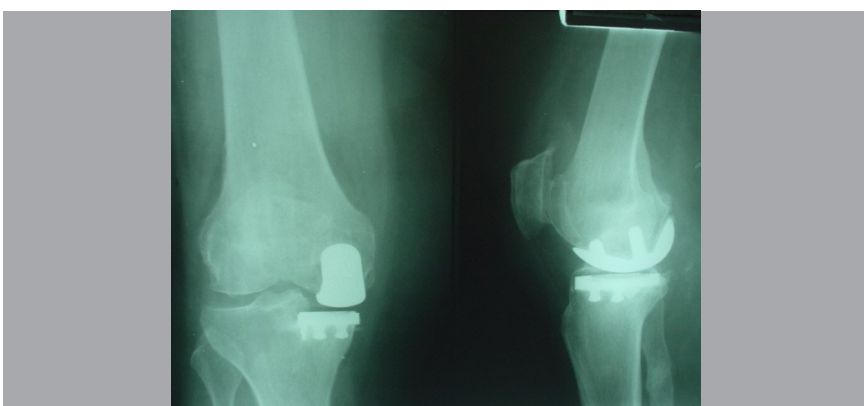

Figure 1. Patient with 186 months of UKA evolution with $x$-ray signs of patellofemoral arthrosis.

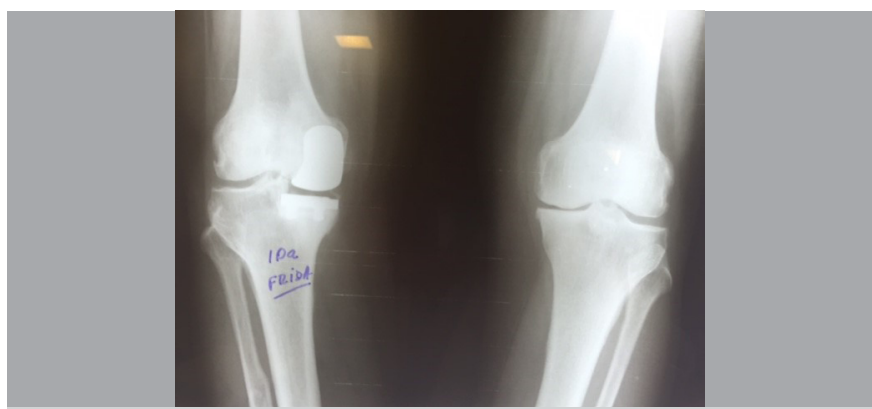

Figure 2. Anterior-posterior radiographs of knees, demonstrating the worsening of varus deformity.

Most patients complaining of pain are patients with patellofemoral arthrosis with radiographic imaging.

\section{DISCUSSION}

In 2007 we published ${ }^{2}$ our experience with UKA, this work already presented evidence that the results over the first 10 years were favorable.

In 2004 we published ${ }^{4}$ a specific study, only on cases of primary osteonecrosis of the knee, as at the time it was called the insufficiency fracture. We also had favorable results in the treatment of this specific pathology.

The indication is rigid, we operate patients with medial arthrosis and stable knees, that is, without anterior cruciate ligament degeneration. The Ahlbäck ${ }^{3}$ classification guides us regarding knee stability, up to grade III and some grade IV cases can be considered as stable knees (Figure 3).

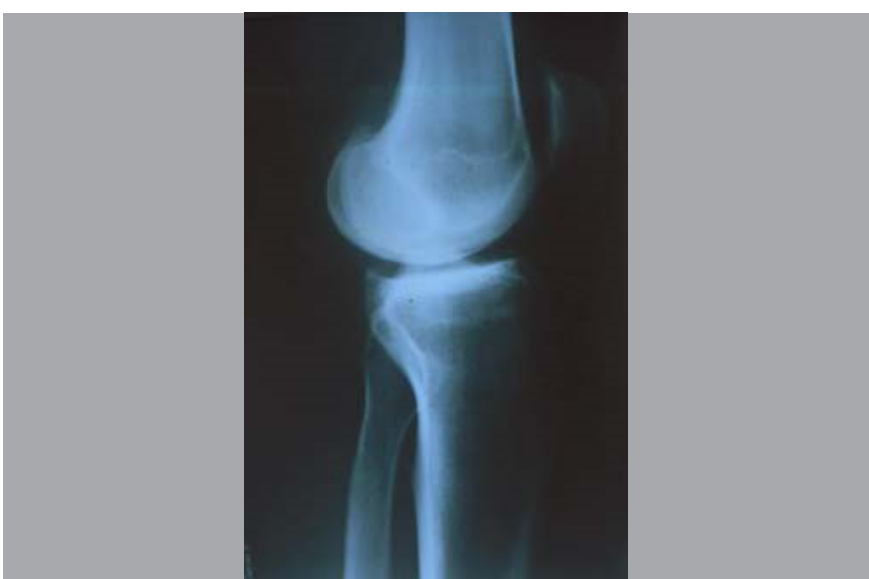

Figure 3. Lateral radiography of knee demonstrating anteriorization of the tibia due to ACL failure. The osteophyte in tibia is characteristic of this degree.

Berger et al., ${ }^{5}$ with whom we learned the technique, reported results similar to ours in patients up to 10 years of follow-up.

In our study we included patients with 15 years of minimum follow-up, and we found that the distribution, regarding sex is very similar, but obviously age is still more advanced.

Out of the 46 patients who would have reached 15 years of evolution, six died of natural causes, one suffered a fracture and only three required revisions, due to UKA failures (6.5\%). There was one case of varus worsening, but without patient's complaints (Figure 2). In the first indications of UKA in the literature, the authors stated that the patient should be older than 60 years. Some of our patients were operated before the age of 60 . Pennington et al. ${ }^{6}$ report $98 \%$ of good 
results in patients under 60 years old, operated with the Miller-Galante prosthesis, the same prosthesis we have used in all cases.

Kennedy et al. ${ }^{7}$ in a long study report that age does not worsen the evolution of UKA, authors believe that the lower demand for age is the cause of this good evolution.

In our initial material, UKA accounted for 10 to $15 \%$ of all arthroplasties we operate, and this trend continues,

There is a very strict limitation of indication, especially regarding Ahlbäck's criteria of anterior knee stability.

Murray et al. ${ }^{8}$ believe that in some procedures the review rate is higher than in total arthroplasty, because there are few UKA surgeries, and surgeons have less training in procedure.

Mohammad et al., ${ }^{9}$ in an extensive review with 8,000 cases made by metanalysis, report that reviews resulting from problems with the prosthesis are more frequent in total arthroplasties than in cases of UKA.

In our results, the pain reported by the patients was bearable, no patient required any additional measure to minimize pain and the most frequent cause of pain was presented in patients with patellofemoral arthrosis, with radiographic imaging. Hamilton et al. ${ }^{10}$ report their experience with the Oxford prosthesis and 15 years of follow-up, the authors believe that patellofemoral arthrosis cannot be considered as a cause of pain in these patients or as a contraindication for UKA. We considered patellofemoral arthrosis with radiographic imaging, a contraindication for UKA.

Motor limitations, which we included the use of cane, were not attributed to problems with UKA in any case. There were imbalances and instabilities appropriate to the patients' age.

With a different model, but with the same concept, the Oxford unicompartmental prostheses present good results with long-period follow-ups. This type of prostheses has mobile plastic, unlike MillerGalante, in which plastic is fixed.

We had no case of release, nor cases of neccessary change of the prosthesis plastic (Figure 4).

A curious case occurred with the second patient who made the UKA with the Miller-Galante prosthesis. Without noticing us, the patient sought the knee outpatient clinic of the Institute of Orthopedics of the Hospital da Clinicas of USP, with a 21-year history of surgery and knee pain.

As the x-rays were normal, a surgical exploration was performed, which found that the plastic was still normal.

An interesting fact, we found a low incidence of arthrosis evolution, a fact that we had already observed in the 2007 series, with up to 10 years of follow-up (Figure 5).

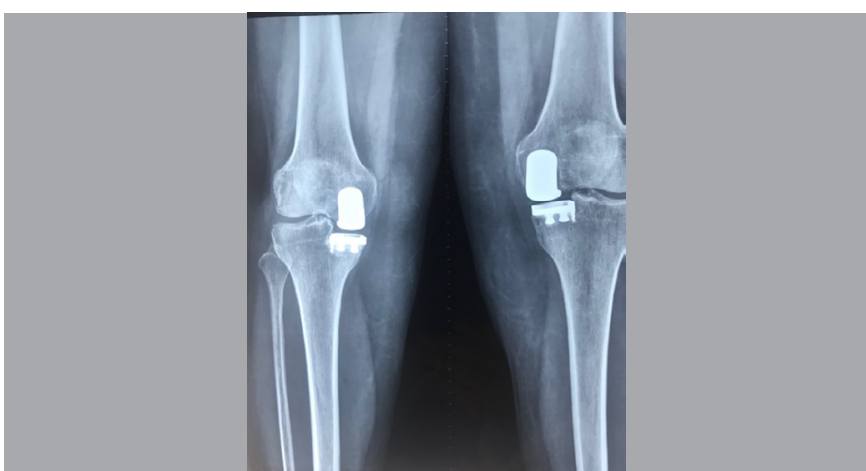

Figure 4. Bilateral unicompartmental arthroplasty, with radiography of the left reader with 184 months of evolution. The one on the right is 96 months old.

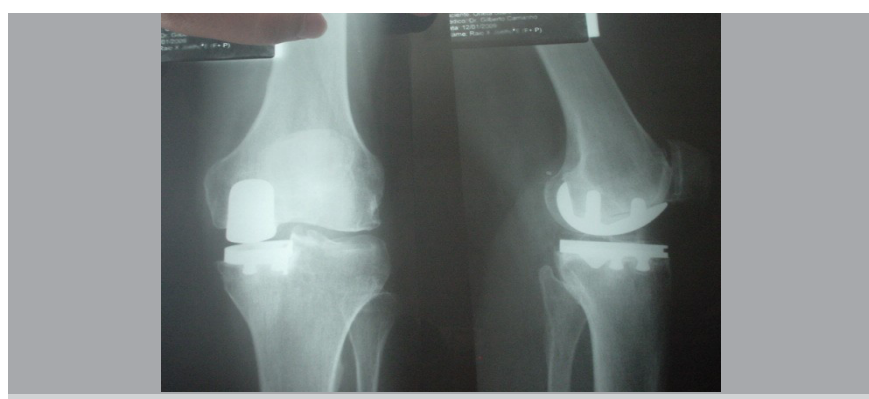

Figure 5. Radiography of a patient with 192 months of evolution, no signs of arthrosis in the knee.

We believe that medial arthrosis is an evolutionary process ${ }^{11}$ and the correction with UKA prevents the evolution to knee arthrosis. Regarding the solidity of the results, we believe that the correct indication is fundamental, the limit is the anterior stability and the degree of deviation clearly defined by Ahlbäck's work.

\section{CONCLUSION}

Unicompartmental knee arthroplasty is efficient to treat medial knee arthrosis after the 15-year evolution of surgery in older patients.

AUTHORS' CONTRIBUTIONS: The author contributed individually and significantly to the development of this article. GLC: wrote and reviewed the article and contributed to the intellectual concept of the study.

\section{REFERENCES}

1. Veiga LT, Villardi AM, Palma IM, Vieira LAM, Leite JER, Dias MSS. Artroplastia unicompartimental do joelho: experiência após 22 casos. Rev Bras Ortop. 1997;32(5):374-6

2. Camanho LM, Viegas AC, Camanho LF, Camanho CR, Forgas A. Artroplastia unicompartimental no tratamento da artrose medial do joelho. Rev Bras Ortop 2007;42(9):285-9.

3. Ahlbäck S. Osteoarthrosis of the knee. A radiographic investigation. Acta Radiol Diagn (Stockh). 1968;Suppl 277:7-72.

4. Camanho GL, Rossetti AC, Camanho LF, Albuquerque RP. Artroplastia unicompartimental do joelho no tratamento da osteonecrose primária do côndilo femoral medial. Rev Bras Ortop. 2004;39(9):486-91.

5. Berger RA, Meneghini RM, Jacobs JJ, Sheinkop MB, Della Valle CJ, Rosenberg $A G$, et al. Results of unicompartmental knee arthroplasty at a minimum of ten years of follow-up. J Bone Joint Surg Am. 2005;87(5):999-1006.

6. Pennington DW, Swienckowski JJ, Lutes WB, Drake GN. Unicompartmental knee arthroplasty in patients sixty years of age or younger. J Bone Joint Surg Am. 2003;85(10):1968-73.
7. Kennedy JA, Matharu GS, Hamilton TW, Mellon SJ, Murray DW. Age and outcomes of medial meniscal-bearing knee arthroplasty. J Arthroplasty. 2018;33(10):3153-9.

8. Murray DW, Parkinson RW. Usage of unicompartmental knee arthroplasty. Bone Joint J. 2018;100-B(4):432-5.

9. Mohammad HR, Strickland L, Hamilton TW, Strickland L, Murray DW. Long-term outcomes of over 8,000 medial Oxford phase 3 unicompartmental knees - a systematic review. Acta Orthop. 2018; 89(1):101-7.

10. Hamilton TW, Pandet HG, Maure DW, Jerkins C, Murray DW. Anterior knee pain and evidence of osteoarthritis of the patellofemoral joint should not be considered contra indication to mobile-bearing unicompartmental knee arthroplasty. Bone Joint J. 2017;99-B(5):632-9.

11. Camanho GL. Artrose medial do joelho, uma patologia de evolução progressiva. Rev Bras Ortop. In press. 